\title{
The Impact of Government Policy and Transition Reforms on Economic Growth - The Case of Kosovo
}

\author{
Myrvete Badivuku-Pantina, PhD
}

\author{
University of Prishtina \\ myrvete.badivuku@hotmail.com \\ Jeton Zogjani, MSC
}

zogjanijeton@gmail.com

\section{Doi:10.5901/ajis.2015.v4n1s2p165}

\begin{abstract}
In this research paper is analyzed the impact of government policy and transition reforms on Economic Growth (in Kosovo) in period of time 2011 - 2014. The variables that are used are as following: economic growth (as dependent variable), corruption index, political stability, exchange rate, transition reforms, control of corruption, and labor market (as independent variables). The data collections are from international and domestic institutions. They are used and calculated through STATA program. The main objectives in the research paper are as following: What is the effect of these factors in economic growth during period time of research? What is the impacted of corruption and control of corruption in economic growth? What is the stimulation of economic growth by government effectiveness, transition reforms and labor market? How much is the correlation between economic growth? The data are calculated by different regression methods: descriptive statistic, OLS method of regression, correlation matrix. In OLS method, the result shown that only transition reforms have positive impact on economic growth but all other reforms have negative impact. Based on this all variables in T-statistic analysis have shown negative significance $(T<2)$ on economic growth. In correlation matrix, transition reforms and government effectiveness have shown positive correlation excluding all other variables that have shown negative correlation with economic growth.
\end{abstract}

Keywords: correlation, corruption, regression, STATA analysis, transition reforms

\section{Introduction}

After the demise of the communist system in the all SEE countries there was a difference in which SEE countries always gave efforts to raise economic growth and the standard of welfare of their people. Some of these countries were experiencing higher economic growth while other countries were experiencing lower economic growth and deterioration living standards, (Bojadzieva, 2005). Transition process is followed by political instability, difficult reforms in domestic markets, challenges in economic development, high level of corruption and bureaucracy costs. In general, transition process has an imposing impact on almost every field of society in transition countries. In developing countries in order to achieve sustainable economic growth, these key challenges must be taken into account: savings, inadequate workforce, weak government institutions, deterioration of competition trade (RIInvest, 2005). According to SELDI Report (2014) \& (Wallacea. C \& Latcheva, R, 2006), when economic growth is high, it may dominate against corruption otherwise it may have consequences in fiscal policy and high deficit. It will seriously impair the education, healthcare and welfare systems.

The Republic of Kosovo since 1999 to 2008 was administered by international community (UNMIK), which later in 2008 was replaced by EULEX. During the period of UNMIK administration, economic growth has been the main focus for governments' policy but the growth always has been associated with lots of challenges, especially in labor market (insufficient policy to reduce unemployment rate), small innovation in private sector, net export (11\% of trading activities), non-competition market, lack of potential markets and the informal economy which has constituted over $40 \%$ of GDP,\&

According to IMF Report, (2013), the main elements for a long term strategy that may improve and develop economic growth in Kosovo, are as following: investments in education and public infrastructure, development of SME sector, the maintenance of flexible labor markets, development and improvment of reforms in the business climate. According to Transparency International Report, (2014) one of the major problems in Kosovo is corruption; in fact Kosovo is the country with the highest level of corruption in the region (Kosovo's index of corruption is 33 out 100, it means very high score). 


\section{Literature Review}

Different authors (Havrylyshyn \& Wolf 1999) \& (Staehr, 2003) have shown that the main factors which determine economic growth in transition countries are: control of inflation, market reforms or trade liberalization, enterprise reform and privatization, development of the private sector. All of these factors have direct impact on growth performance than in countries which have experienced slower growth? According to CBK Report, (2014) economic developments in Kosovo during 2013 has annual growth 3.4 \% (or 0.6 \% higher than 2012) and it is as a result that all sectors of the Kosovo's economy were mainly positive. Despite consequences of financial crisis, Kosovo has managed to have an average GDP growth $3.3 \%$ last few years. Kosovo is one of the few countries in the Western Balkan that have positive growth (Fabris, 2014). However Kosovo's GDP still continues to have an annual growth below 4\%, which is as a result of not creating government institutions more than 6 months in the 2014. According to IMF Report, (2014) annual growth of GDP in 2014 is $2.7 \%$ and in 2015 the projection of real GDP growth is about $3.3 \%$, it is approximately with average growth in most of SEE countries (see Figure 1) then projection of GDP will be approximately $4-4.5 \%$ until 2019 and it is very low to overcome economic, social and welfare challenges in Kosovo.

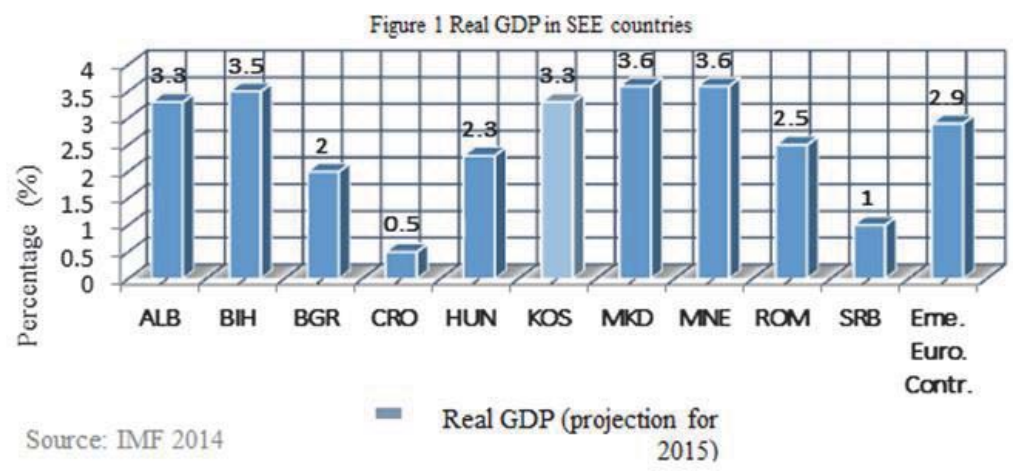

Many authors have researched the relationship between corruption and economic growth; most of them agree that corruption has a negative impact in economic growth (Mauro, P, 1997) \& (Mo, 2001) \& (Aidt, 2009). As argued (Farooq et al, 2013) \& (Osipian, 2012), in long time aspect, corruption impedes economic growth especially in financial development (weakens the financial capital), free trade (reduces domestic production) and human development (reduces the level of human capital and slows the pace of its development). According to UNODC Report (2013) corruption, bribery, high taxes and political instability are the biggest obstacles for business environment in Kosovo and it has impact in whole Kosovo's economy. According to Transparency International Report, (2014) the level of corruption is high in the most of SEE countries (95\%) and Kosovo is one of the countries with the highest level of corruption in the region (33 out 100), for more details see table below:

Table 1. Index of Corruption in West Balkan countries

Country:
Albania
Bosnia and Herzegovina
Croatia
Kosovo
Montenegro
Serbia
Macedonia

Average
31.6
41.0
47.3
33.3
42.3
40.6
44.0

2014
31
39
48
33
42
41
45

$\begin{array}{cc}2013 & 2012 \\ 31 & 33 \\ 42 & 42 \\ 48 & 46 \\ 33 & 34 \\ 44 & 41 \\ 42 & 39 \\ 44 & 43\end{array}$

Source: Transparency International Report 2014, 2013, 2012

As argued by (Dzhumashev, 2014) \& (Graeff \& Mehlkopb 2003), in many countries the main significant factors on reduction of corruption level are: the quality of governance, the level of economic development, the amount of public costs, free trade and liberal economy. Therefore countries with high level of governmental corruption have a huge negative impact on economic growth (Kunieda et al, 2014). In context of transition reforms, $79 \%$ of the initial reforms in 
the EBRD countries consisted in three main reforms: privatization, structural reforms and liberalization (Staehr, 2003). Political stability has significant effect in economic growth in most of the Balkan countries while lack of political stability will reduce economic growth and FDI (Brada et al, 2006). The positive effects on the correlation between market reforms and economic growth have existed in the most transition countries. These positive effects can act as an immediate stimulant to further reforms in these countries, (Falcetti et al, 2005). Serious reforms that are focused mostly on free trade economies, in strengthening the economic sustainability and political stability are key factors of growth in transition economies (include Kosovo), (Rllnvest, 2005).

\begin{tabular}{|ccccc|}
\hline Country: & Average & 2014 & 2013 & 2012 \\
\hline Albania & 31.6 & 31 & 31 & 33 \\
\hline Bosnia and Herzegovina & 41.0 & 39 & 42 & 42 \\
\hline Croatia & 47.3 & 48 & 48 & 46 \\
\hline Kosovo & 33.3 & 33 & 33 & 34 \\
\hline Montenegro & 42.3 & 42 & 44 & 41 \\
\hline Serbia & 40.6 & 41 & 42 & 39 \\
\hline Macedonia & 44.0 & 45 & 44 & 43 \\
\hline
\end{tabular}

In this paper as important issues for discussion are different economic activities that constitute overall economic growth, these include different sectors that produce a large number of goods and services. According to ASK Report, (2015) the main economic activities in Kosovo's economy are as following: agriculture $23.6 \%$, wholesale and retail trade $21.9 \%$, processing industry $16.9 \%$, construction $11.4 \%$, etc (further details see Appendix 1). In this paper as an important issue for discussion are macroeconomic aggregates (components) of GDP (consummation, investment and net export). In general, the majority of Kosovo's GDP consists by consumption rather than investments and net exports, CBK Report (2014). According to CBK Report (2015), by analyzing the progress of these aggregates in recent years, only consumption has positive trend while investments and net exports have negative performance during the years 2012 and 2013 (for more details see the table below).

Figure 2. Factors that determine economic growth in Balkan countries

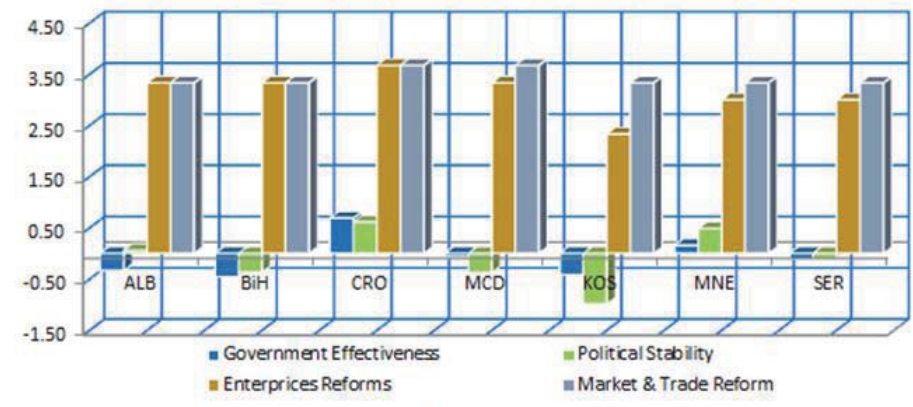

Source: The World Bank 2014; EBRD 2014

\section{Methodology and Data}

In order to estimate the impact of government policy and transition reforms on economic growth in case of Kosovo, in paper secondary data are used. The data collection is realized by taking data from different reports and publications by international institutions (like as: World Bank, IMF, EBRD, etc), domestic institutions (like as: CBK, ASK, etc) and most of the data for analysis include the period of time 2011 - 2011. Numbers of variables that are taken from these reports are as following: economic growth (depend variable), corruption index, political stability, government effectiveness, transition reforms, control of corruption, labor market (independent variables). By means of the econometric STATA program have been used different regression methods for analysis (Descriptive Statistics, Ordinary Least Squares - OLS Method and Correlation Matrix) which helps us to find the relationship between variables that are included in this paper. The main regression analyze will be based on the following equation: $\operatorname{Ln}(E G t)=\beta 0+\beta 1 \ln (C I t)+\beta 2 \ln (P S t)+\beta 3 \ln (G E t)+\beta 4 \ln (E R t)$ $+\beta 5 \ln (\mathrm{MRt})+\beta 6 \ln (\mathrm{CC} t)+\beta 7 \ln (\mathrm{TRt})+\varepsilon \mathrm{t}$. 


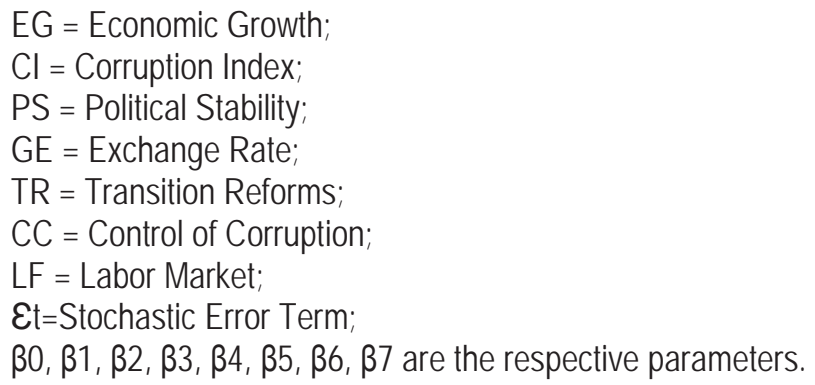

\section{Empirical Results and Interpretations}

This part of the research paper will reflect the results achieved and this actually constitutes the main part of paper research because there will realize the main analysis of statistical methods (Statistic descriptive, Ordinary Least Squares method, Correlation method) by STATA program and the dates (or variables) include period of time from 2011 - 2014. Statistic descriptive method is quantitative discipline that describes the main features of a quantitative description of the variables. In table 2, the minimum value of economic growth (EG) is $2.7 \%$ (it means, the lowest value of "EG" in period of research) and maximum is $4.4 \%$ (it means the highest value of "EG" in period of research), the mean is $3.7 \%$ (it means average value of "EG" in period of research) and standard deviation is $1.04 \%$ (it means, the "EG" variable is quite close between them $2.5 \%$ to $5.4 \%$ ). Corruption Index ( $\mathrm{Cl}$ ) having minimum value is (29 ranking in global index), maximum is (34 ranking in global index) then the mean and standard deviation are (32.5 \& 0.22)

Table 2. Statistics Descriptive Method

Source: Author

$\begin{array}{cccccc}\text { Variable } & \text { Observation } & \text { Std dev } & \text { Min } & \text { Mean } & \text { Max } \\ \text { EG } & 4 & 0.78 & 2.7 & 3.25 & 4.4 \\ \text { CI } & 4 & 0.22 & 29 & 32.2 & 34 \\ \text { PS } & 4 & 1.80 & 13.7 & 15.75 & 18 \\ \text { GE } & 4 & 1.63 & 48.8 & 51.22 & 52.2 \\ \text { TR } & 4 & 0.48 & 2.33 & 2.99 & 3.33 \\ \text { LF } & 4 & 8.00 & 23.9 & 31.9 & 40.5\end{array}$

Political stability (PS) having minimum index value (13.7), maximum index value (18), the mean value is (15.7) and standard deviation is (1.80). Government Effectiveness (GE) has bigger values than other variables, so minimum index (48.8), maximum index (52.2), the mean value (51.2) and standard deviation (1.63). Transition Reforms (TR) have smaller values than other variables, minimum and maximum are (2.33 \& 3.33), mean and standard deviation (2.99 \& 0.48). The minimum of Labor Force is (23.9\%) and maximum value is (40.5 \%) then mean (31.9 \%) and standard deviation (31.9\%). In Table 3, we estimate parameters (variables) through linear regression model and comment of OLS method is as following: corruption $(\mathrm{Cl})$ is -3.27 and it means when corruption increase per a unit, it will have negative impact $(\beta 2=-3.27)$ on economic growth, it always is understandable that other variables (PS, GE, TR, and LB) are constant / fixed. Also other variables, such as: Political Stability ( $\beta 3=-0.33)$, Government Effectiveness $(\beta 4=-5.49)$ and Labour Force $(\beta 6=-0.03$ ) have negative impact on economic growth. Transition Reforms is only variable with positive impact $(\beta 6=1.29)$ on economic growth

Table 3. Test of Ordinary Least Squares (OLS) Method

Source: Author

Economic Growth
Constant
Corruption Index
Political Stability
Government Effect.
Transition Reform
Labor Force

Coefficient
2.65
-3.27
-0.33
-5.49
1.29
-0.03

Std Err
2.10
0.92
0.20
3.88
0.70
0.06

T-statistic
2.75
-3.56
-1.68
-1.41
1.83
-0.54

$\begin{array}{cc}\text { P-value } & \mathbf{R}^{\mathbf{2}} \\ 0.74 & 0.99 \\ 0.07 & \\ 0.23 & \\ 0.29 & \\ 0.21 & \\ 0.64 & \end{array}$


Through T-statistics, means the explanatory capability (or significance) positive $(T>2)$ or negative $(T<2)$ that the independent variables have on the dependent variable. All variables in $T>|t|$ analysis has shown negative significance $(\mathrm{T}<2)$ on economic growth because all of them have negative value. In table 3 is coefficient of determination (R2), so question is: What does mean the determination coefficient $\left(R^{2}=0.99\right)$ between variables that are include in the paper research? It tells us: a) the relationship is positive between them (it has positive value); b) the relationship between variables is quite strong (since the value is pretty close to 1 ) while only $0.01 \%(100 \%-99 \%)$ are other factors that are not included in this model.

Table 4. Correlation Matrix

$\begin{array}{lcccccc} & \text { EG } & \text { Cl } & \text { PS } & \text { GE } & \text { TR } & \text { LF } \\ \text { EG } & 1.00 & & & & & \\ \text { Cl } & -0.93 & 1.00 & & & & \\ \text { PS } & -0.76 & 0.62 & 1.00 & & & \\ \text { GE } & 0.33 & -0.40 & 0.35 & 1.00 & & \\ \text { TR } & 0.80 & -0.51 & 0.75 & 0.10 & 1.00 & \\ \text { LF } & -0.36 & 0.26 & 0.86 & 0.76 & -0.40 & 1.00\end{array}$

Source: Author

Correlation matrix analyzes the relationship between independent variables and dependent variable that are included in the paper research. The relationship between economics growth (as depend variable) and transition reforms (as independent variable) is positive correlation with 0.80 , it is almost positive strong correlation also government effectiveness 0.33 has positive correlation on economic growth but it is not strong correlation like transition reforms. Correlation between economic growth and corruption is negative -0.90 , it is almost negative strong correlation also political stability -0.76 and labor force -0.36 has negative correlation.

\section{Conclusion}

In this research paper is analyzed the impact of government policy and transition reforms on economic growth with case study of Kosovo. Data that are used included period of time 2011 - 2011 and they are calculated by STATA program and the main regression analysis are as following: descriptive analysis, multiple regression analysis and matrix correlation analysis. In the main analysis in research is OLS regression method, it shown the results that only transition reforms have positive impact ( $\beta 6=1.29)$ on economic growth but other variables: corruption ( $\beta 2=-3.27)$, political stability $(\beta 3=-0.33)$, government effectiveness $(\beta 4=-5.49)$, control of corruption $(\beta 4=-5.49)$ and Labour Force $(\beta 6=-0.03)$ have negative impact on economic growth. T-statistic analyze shown that all variables have shown negative significance $(T<2)$ on economic growth. Lastly, correlation matrixes the results are as following: transition reforms and government effectiveness have shown positive correlation but all other variables have shown that negative correlation with economic growth.

\section{References}

Aidt, T. (2009). Corruption, institutions, and economic development. Oxford Review of Economic Policy, 25 (2), 271 - 291.

ASK Report. (2015). General Statistics: Quarterly Bulletin, Series 1. Prishtinë: Kosovo Agency of Statistics (KAS): Staff Publication.

Bojadzieva, H. (2005). Factors of Economic Growth in the Transition Economies of Eastern Europe: The Case of Macedonia. Issues in Political Economy, 14, 1 - 14.

Brada et al. (2006). The effects of transition and political instability on foreign direct investment inflows Central Europe and the Balkans. Economics of Transition, 14 (4), 649 - 680.

CBK Report. (2014). Annual Report 2013. Prishtine: CBK: Staff Publication Servise.

CBK Report. (2014). Macroeconomic Developments Report, Number 1. Prishtina: CBK: Publication Services.

CBK Report. (2015). Report of macroeconomic development, No 2. Prishtine: CBK: Department of Publication.

Creswell, J. W. (2009 p.4). Research Design; Qualitative, Quantitative and Mixed Methods Approaches. 2nd ed. London: SAGE Publication Ltd.

Dzhumashev, R. (2014). Corruption and growth: The role of governance, public spending, and economic development. Economic Modelling, 37, 202 - 215. 
EBRD. (2013). Private Sector Development: Innovative System Assessment of Kosovo. Paris: OECD Investment Compact for South East Europe.

Fabris, C. (2014). Department of State: 2014 Investment Climate Statement . Prishtina: US Office Prishtina: Economic and Commercial Officer.

Falcetti et al. (2005). Reforms and growth in transition: re-examining the evidence. Working paper No. 90. One Exchange Square, London: EBRD - Transition Report 2004.

Faroog et al. (2013). Does corruption impede economic growth in Pakistan ? Economic Modelling, 35, 622 - 633.

Graeff, P. \& Mehlkopb, G. (2003). The impact of economic freedom on corruption: different patterns for rich and poor countries. European Journal of Political Economy, 19, 605 - 620.

Havrylyshyn \& Wolf. (1999). Determinants of Growth in Transition Countries. IMF: Finance and Devolopment, 36 (2).

IMF Report. (2013). Republic of Kosovo - 2013 Article IV Consultation, IMF Country Report No. 222. Washington: IMF: Publication Services.

IMF Report. (2014). World Economic Outlook: Legacies, Clouds, Uncertainties. Washington: IMF: Publication Services.

Kunieda et al. (2014). Corruption, capital account liberalization, and economic growth: Theory and evidence. International Economics, $139,80-108$.

Mauro, P. (1997). Why Worry About Corruption ? Washington D.C: International Monetary Fund, Publication Services, ISBN 1-55775635- $\mathrm{x}$.

Mo, P. (2001). Corruption and Economic Growth. Journal of Comparative Economics, 29, 66-79

MTI. (2009). Trade policy of Kosovo. Prishtina: Ministry of Trade and Industry: Staff Report.

Osipian, A. (2012). Education corruption, reform, and growth: Case of Post-Soviet Russia. Journal of Eurasian Studies, 3, 20 - 29.

RIInvest Institute. (2005). Economic sustainability of Kosovo (challenges, policies and opportunities). Prishtina: RIInvest Institute.

SELDI Report. (2014). Anti-Corruption Reloaded: Assessment of Southeast Europe. Sofia, Bulgaria: Center for the Study of Democracy.

Sen \& Kirkpatrick. (2009). A Diagostic Approach to Economic Growth and Employment Policy in Low Income Economies: The Case of Kosovo. Manchester: Impact Assessment Research Center (IARC) - Working Papers Series, No. 25/2009 .

Staehr, K. (2003). Reforms and economic growth in transition economies: Complementarity, sequencing and speed. Institute for Economies in Transition BOFIT - Discuss Paper, 1, 1-35

Transparency International Report. (2014). Transparency International Corruption Perceptions Index 2014. Berlin: Transparency International: International Secretariat.

UNODC Report. (2013). Business, Corruption and Crime in Kosovo: The impact of bribery and other crime on private enterprise. Vienna: UNODC: Statistics and Surveys Section (SASS).

Wallacea. C \& Latcheva, R. (2006). Economic Transformation Outside the Law: Corruption, Institutions in Transition Countries of CEE Europe. Europe-Asia Studies, 58 (1), 81 - 102.

\section{Appedix A}

\section{Economic activities of GDP in Kosovo (2014)}

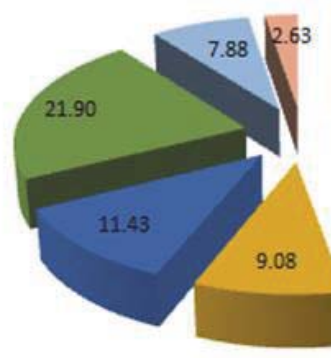

Source: KAS 2014
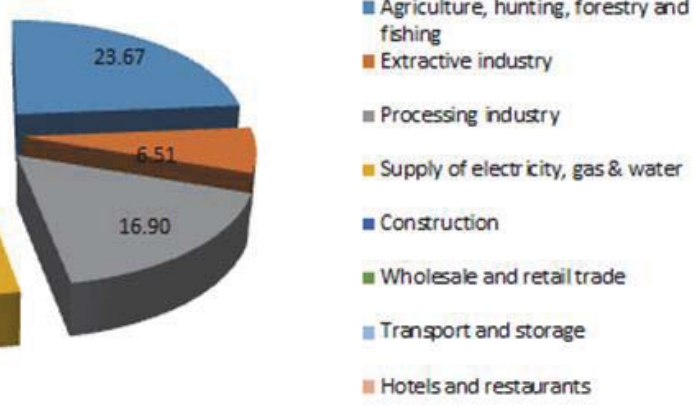


\section{Appedix B}

Table 4: Data used for analysis

\begin{tabular}{cccccc} 
Economic Growth & Corruption Index & Political Stability* & Government Effectiveness* & \multicolumn{2}{c}{ Transition Reform } \\
2.7 & 33 & 18.0 & 52.2 & 2.33 & 40.5 \\
3.4 & 33 & 16.1 & 52.2 & 3.33 & 36.8 \\
2.8 & 34 & 15.1 & 48.8 & 3.83 & 23.9 \\
4.4 & 2.9 & 13.7 & 51.7 & 3.83 & 26.4
\end{tabular}

Source: Economic Growth - IMF 2014; Corruption Index - Transparency International 2014; Political Stability \& Government Effectiveness - World Bank (WGI) 2014; Transition Reform - EBRD 2014; Labor Force - The Kosovo Agency of Statistics 2015

\section{Appedix C}

Table XX: Variable Definitions and Sources

\begin{tabular}{|c|c|c|}
\hline Variables: & Description: & Source: \\
\hline Dependent Variable: & & 4. \\
\hline $\begin{array}{ll}\text { 5. } & \text { Economic Growth } \\
\text { 6. } & \text { (Real GDP) }\end{array}$ & $\begin{array}{l}\text { 7. Real GDP is defined as the value of the total final output (of all } \\
\text { goods and services) that is produced in a one year within a } \\
\text { country's boundaries and the growth / decrease of Real GDP } \\
\text { is expressed as a percent (\%). }\end{array}$ & $\begin{array}{ll}\text { 8. IMF: World Economic } \\
\text { Outlook } 2014\end{array}$ \\
\hline 2. Independent Variables: & 9. & 10. \\
\hline 11. Corruption Index & $\begin{array}{l}\text { 12. The Corruption Perception Index (CPI) ranks countries based } \\
\text { on how corrupt their public sector is perceived to be. CPI is a } \\
\text { composite index, a combination of polls, drawing on } \\
\text { corruption-related data collected by a variety of reputable } \\
\text { institutions. High score of corruption start from } 0 \text { - } 100 \text { and } \\
\text { countries with corruption from } 100 \text { - } 0 \text { are very clean in front } \\
\text { corruption. }\end{array}$ & $\begin{array}{ll}\text { 13. } & \text { Transparency } \\
\text { 14. } & \text { International: } \\
\text { 15. } & \text { Annual Report } 2014\end{array}$ \\
\hline 16. Political Stability & $\begin{array}{l}\text { 17. Reflects perceptions of the likelihood that the government will } \\
\text { be destabilized or overthrown by unconstitutional or violent } \\
\text { means, including politically - motivated violence and terrorism. }\end{array}$ & $\begin{array}{l}\text { 18. World Bank: } \\
\text { The Worldwide Governance } \\
\text { Indicators (WGI) } 2014\end{array}$ \\
\hline 19. Government Effectiveness & $\begin{array}{l}\text { 20. Government Effectiveness (GE) - Reflects perceptions of the } \\
\text { quality of public services, the quality of the civil service and the } \\
\text { degree of its independence from political pressures, the quality } \\
\text { of policy formulation and implementation, and the credibility of } \\
\text { the government's commitment to such policies. }\end{array}$ & $\begin{array}{l}\text { 21. World Bank: } \\
\text { The Worldwide Governance } \\
\text { Indicators (WGI) } 2014\end{array}$ \\
\hline 22. $\quad$ Transition Reforms & $\begin{array}{l}\text { 23. The transition reforms range from } 1 \text { to } 4 \text {, so with } 1 \\
\text { representing little or no change relative to a rigid centrally } \\
\text { planned economy and } 4 \text { representing the standards of an } \\
\text { industrialized market economy. }\end{array}$ & 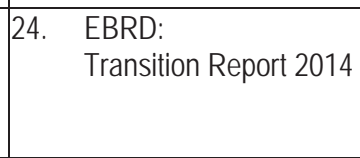 \\
\hline 25. Control of Corruption & $\begin{array}{l}\text { 26. Control of Corruption (CC) - Reflects perceptions of the extent } \\
\text { to which public power is exercised for private gain, including } \\
\text { both petty and grand forms of corruption, as well as "capture" } \\
\text { of the state by elites and private interests. }\end{array}$ & $\begin{array}{l}\text { 27. World Bank: } \\
\text { The Worldwide Governance } \\
\text { Indicators (WGI) } 2014\end{array}$ \\
\hline 28. Labor Force & $\begin{array}{l}\text { 29. Labor Force - is the total number of people employed or } \\
\text { seeking employment in a country / region also it called work } \\
\text { force and in Kosovo include people employed between } 18 \text { to } \\
65 \text { years old. }\end{array}$ & $\begin{array}{ll}\text { 30. } & \text { The Kosovo Agency of } \\
& \text { Statistics (ASK) }\end{array}$ \\
\hline
\end{tabular}

Source: Author 
